\title{
Global Justice: Just Another Modernisation Theory?
}

\section{Anne Phillips ${ }^{1}$}

Debates about global justice find little resonance amongst scholars in the postcolonial world. ${ }^{2}$ At one level, the reason is obvious: this is not their problem. The literature on global justice primarily concerns itself with the obligations of citizens and governments in the richer countries towards those in poorer ones. To put it more historically, it asks what those who are beneficiaries of colonialism and imperialism owe to those who were subjected to imperial power. The addressees are not those located in the post-colonies; nor are they the many millions who used to live there, but later migrated (or fled) to the imperial centres. It is, indeed, one of the oddities of the literature that it poses questions about global responsibility without always taking on board the nature of contemporary globalisation. In its pursuit of what 'we' owe to 'distant others', ${ }^{3}$ it treats the global north and south as relatively discrete and distant entities, overlooking the many ways in which the empire has come home. ${ }^{4}$ In asking whether principles of domestic egalitarian justice can or should be applied to the global realm, ${ }^{5}$ it presumes a separation that is already challenged by patterns of global migration.

The lack of resonance is substantive as well as perspectival, for it also reflects a mismatch between the post-national, post-communal, post-ethnic framework of much global justice debate and the institutional legacies of colonial power. Global justice typically speaks to us as individuals, stressing our rights and obligations as human beings rather than as members of a community or citizens of a nation. As Margaret Kohn notes, it is embedded within an analytic framework, usually either Kantian or utilitarian, that takes the moral obligations of the individual as its primary concern. ${ }^{6}$ States will of course figure in this: if the obligations are discharged, it will be mainly through state action, not as a result of individual citizens increasing their donations to development charities. But especially for the more cosmopolitan inclined theorists, the nation state is not the moral centre. They take issue, to the contrary, with state-centric understandings of responsibility and loyalty, elevating a normative universalism that conceives of us as in our persona as individual human beings over the (by implication) parochialism of the national community. In World Poverty and Human Rights, Thomas Pogge characterises cosmopolitanism as composed of three elements, the first of which is the view that 'the ultimate units of concern are human 
beings, or persons - rather than, say, family lines, tribes, ethnic, cultural, or religious communities, nations, or states. The latter may be units of concern only indirectly, in virtue of their individual members or citizens. ${ }^{7}$ In Justice Beyond Borders, Simon Caney identifies three main challenges to global conceptions of justice - realism, nationalism, and 'the society of states' - and sees all of these as characterised by the excess significance they attach to either state or nation. ${ }^{8}$ Most global justice theorists will attach primary normative weight to the individual.

There are global justice theorists who regard nation states as ethically significant: Daniel Butt, for one, contrasts his approach to that of cosmopolitanism, and sees his work on Rectifying International Injustice as identifying the rectificatory duties of beneficiary states towards those they colonised or otherwise treated unjustly. ${ }^{9}$ Methodologically, however, Butt's approach is strikingly similar to that of the more cosmopolitan theorists. In particular, he extrapolates the principles of justice that ought to regulate relations between nations from principles that ought to regulate relations between individuals; ${ }^{10}$ and he represents nations very much as agglomerations of individuals, referring to 'modern-day populations' or 'present day generations' or 'overlapping generations', as if there were no significant stratifications intervening between the individual and the state. ${ }^{11}$ Even, that is, where national boundaries are taken as ethically significant, and the post-national impetus is explicitly rejected, the framework remains fundamentally individualist.

Other papers in this collection also draw attention to the methodological and normative individualism of much global justice theory. Samuel Moyn goes so far as to argue that the commitment to normative individualism was forged in resistance to the focus on state action and national self-determination that characterised the anti-colonial and immediately postcolonial movements. ${ }^{12} \mathrm{He}$ argues that the global justice literature shares with the subsequent neo-liberal order an indifference to state autonomy, as did the human rights revolution, which focuses on the individual regardless of citizenship or location and tends, if anything, to consider nation states as the enemy. States then figure mainly as the abusers of human rights, and corrupt state officials are seen as contributing significantly (as indeed they do) to continuing inequalities. Kimberley Hutchings similarly draws attention to the methodological and normative individualism that pervades global justice theory, focusing, in her essay, on the subset of this that addresses the ethics of war. Here, the 
methodological individualism is especially striking. Hutchings argues that the abstraction and individualism that characterises much writing on the ethics of war tends towards a colonial imaginary that locates moral intelligence and moral agency in the West.

My own argument shares much common ground with these, and in particular with the implications of normative and methodological individualism. I focus on two aspects. The first is the mismatch between the assumptions and methodologies of global justice theory and what has been the typical experience of countries subjected to colonial rule: the absence, one might say, of a historical grounding. Colonialism destroyed communities and established historically arbitrary national boundaries, but it did not do so in order to usher in a world of abstract human beings. To the contrary, it largely secured and strengthened ethnic and religious boundaries, laying the basis for what Mahmood Mamdani has described as a 'decentralized despotism.' ${ }^{13}$ The language of global justice neither speaks to nor offers much of a solution to the resulting institutionalisation of ethnic and community identity, for it operates within a post-national individualism that calls on us to go beyond the local towards the global, beyond the national towards the universal. Speaking, as it does, to readers in the global north, it calls on them 'to disregard their private and local, including national, commitments and loyalties to give equal consideration to the needs and interests of every human being on this planet' ${ }^{14}$ But other than reparations (and I do not dismiss the significance of these), it is unclear what this has to offer to readers in the global south.

The first part of my argument addresses what might be described as sins of omission: a tendency to concentrate on some problems to the exclusion of others; to speak to some audiences but not others; a failure adequately to address the more burning issues for the global south. The global justice theorist might reasonably respond that no-one can do everything. My second claim is that this is not just something left undone, but a tendency that helps reproduce relations of power. When we are encouraged to think of what we owe to others as fellow humans, rather than as fellow citizens or fellow Europeans or fellow Igbo, this carries with it, however inadvertently, the suggestion that those who fail to make this normative move remain trapped within an older paradigm. The focus on a person-toperson morality can then be said to reflect a modernist stance, in which the highest form of morality is the one that transcends the specificities of difference. Especially in its more cosmopolitan versions, global justice theory encourages us to view the power of local, 
ethnic and community identification as an as-yet-untransformed traditional, something that holds us back from what justice really demands. In doing so, it suggests a trajectory from tradition to modernity of the kind more commonly associated with modernisation theory and its unthinking identification of modernity with the West.

In what follows, I first draw on some of the literature on modernisation and modernity to clarify pitfalls in conceptions of the modern, and more specifically, to illuminate the role commonly allocated to the individual as emblem of modernity. I then turn to the legacy of colonialism, drawing particularly on sub-Saharan Africa, and use some of that legacy to challenge the traditional/modern dichotomy that suffuses modernisation theory. I then return to global justice theory. I am not, in this essay, claiming an intellectual lineage that stretches from modernisation theory to contemporary work on global justice though the genealogy Katrina Forrester excavates in her contribution to this collection might provide some support for this. My main point is less about historical influences and more about contemporary effects. I suggest that global justice expresses a modernist bias that mirrors some of the now discredited assumptions of modernisation theory.

\section{Modernity and Modernisation}

What is modernisation theory? I use the term to refer to a branch of development theory that thinks of societies as positioned along a continuum stretching from traditional to modern; defines the modern by reference to an (often idealised) version of Western society; and sees the 'problem' of development as a matter of overcoming the obstacles that tradition has set in its path. What counts as an obstacle varies from one version to another, as does the precise specification of traditional and modern, and few modernisation theorists today would endorse Walt Rostow's over-formalised 'five stages' of economic and political growth. ${ }^{15}$ In most cases, however, there will be some variant of the distinction between ascription and achievement: some claim to the effect that 'traditional' societies attribute status on the basis of family, kinship group, or caste, while 'modern' societies attribute status on the basis of achievement. In traditional societies, the story goes, the community is likely to take precedence over the individual; in modern societies, the individual takes precedence over the community. In traditional societies, there is no clear demarcation between economic, political and social power; in modern societies, there is a separation between these spheres. In early modernisation theory there was limited 
nostalgia for the traditions that must be jettisoned in order to move along the route to development. ${ }^{16}$ Later writers, perhaps less confident about the virtues of modernity, have been more ambivalent, worrying that something valuable is lost in the process. The general character of the approach remains: a relatively unself-conscious differentiation between traditional and modern, with the latter modelled on the self-image (rather than reality) of Western societies; and a belief that all societies must eventually make their way along this path if they are to achieve economic growth, development, and democracy. Modernisation theory operates, that is, with what Dipesh Chakrabarty describes as a 'transition narrative': ${ }^{17}$ a 'first in Europe, then elsewhere' understanding of history that takes Europe and America as the model of all that is progressive and advanced, and presumes (at its more optimistic) that other countries must eventually arrive at the same destination, even if they get there by different routes.

This way of viewing historical change is self-evidently vulnerable to criticism, and the death of modernisation theory has been repeatedly announced, from as early as $1976 .{ }^{18}$ In its fundamentals, however, it remains a major paradigm within the social sciences, and a number of commentators have noted its recent revival and reinvention. ${ }^{19}$ In 2005 , to give one example, Ronald Inglehart and Christian Welzel published Modernization, Cultural Change, and Democracy: The Human Development Sequence, presenting a body of evidence to support what they took to be the central insight of modernisation theory: the claim that 'socioeconomic development brings systemic changes in political, social, and cultural life'. ${ }^{20}$ While they represent themselves as offering a revised modernisation theory, the revisions they propose are mainly concerned with challenging the excess determinism of earlier models. 'Other things being equal', they argue, 'socioeconomic development tends to make people more secular, tolerant, and trusting and to place more emphasis on self-expression, participation, and the quality of life. But socioeconomic factors are not the only significant influences' ${ }^{21}$ So religion will not necessarily die out; cultural convergence is by no means guaranteed; and change is not unilinear. The revised version shares, however, with the classics a contrast between the communalism of traditional societies and individualism of modern ones, and differs mainly in insisting on the resilience and robustness of belief systems, even in periods of rapid socio-economic change. It remains vulnerable to the same kind of criticism that has been levelled at earlier versions. 
One objection to modernisation theory is that it is bad history and bad sociology. It represents 'traditional' societies as if they have existed for centuries in splendid isolation, carrying on in their distinctively traditional ways, until propelled by the interventions of international agencies or processes of socio-economic development along the path towards modernity. In doing so, it treats social forms that were in large part produced by global interaction as if they were original conditions, understating the impact of centuries of global commerce, including the slave trade, and later of colonialism and neocolonialism. As critics have argued, societies at the raw end of global interactions are not so much undeveloped as actively underdeveloped, through the loss of their people and raw materials, the destruction of often thriving industries that were unable to compete with new imports, and the creation of new 'traditions' of hierarchy and authority that block further change. ${ }^{22}$ The binary of traditional and modern also misses the interweaving of the alleged alternatives in pretty much every known society. In the ascription/ achievement dichotomy, for example, it is supposed to be traditional societies that position people according to the group they are born into whilst modern societies judge us by what we have managed to do. This ignores both the importance of inherited privilege in so-called modern societies (think of Thomas Piketty's analysis of the way inheritance patterns propel contemporary capitalism into deeper and deeper inequality $\left.{ }^{23}\right)$, and the continuing power of gender and race. The sex we are born into remains an enormously powerful determinant of status in so-called 'modern' societies, in ways that cannot be plausibly represented as an unfortunate hangover from a more disreputable past. The power of gender is better understood as constitutive of all known societies and something that is being continually reproduced.

The further point is that adopting a binary of traditional and modern conveys a normative hierarchy that asserts the superiority of the latter. Though modernity is, at one level, a descriptive term, something we can attach to particular periods in history whilst leaving open for future examination its precise characteristics, it is most commonly normative as well, with the modern as what we aspire to and the traditional as what we seek to leave behind. The binary then performs a hierarchy, and it has proved difficult to dislodge this even in a growing literature that detaches modernity from its more exclusively Euro-American form. Thomas McCarthy, for example, provides a careful critique of the racial hierarchies that have underpinned ideas of human development. He nonetheless ends with 
certain 'practically unavoidable presuppositions of contemporary discourse', some of which hover uncomfortably close to presuppositions of modernisation theory. ${ }^{24}$ In his analysis, the 'facts of cultural and societal modernity' bring with them the necessity of questioning received beliefs, inherited norms, and ascribed identities; encourage reflexivity and toleration of difference; and promote awareness of the possibilities for reasonable disagreement. Even when stripped of the presumption in favour of a European model, and moderated by explicit recognition of social and cultural diversity, this still recalls elements of the traditional/modern divide. ${ }^{25}$

There are similar strains even in Chakrabarty's account of Hindu reformers in late nineteenth/early twentieth century Bengal, reformers who had a strong sense of themselves as modern, drew in many ways on European narratives of modernity, but developed what he identifies as a distinctively Bengali version. In the European narratives, he argues, modernity came to be associated with the capacity to conceptualise individuals as abstracted from specific social context, and in their generalised and disembodied rationality, sustaining the emerging ideas of equality, autonomy, democracy, and nation. The history of Bengali nationalism, by contrast, offers 'a colonial modernity that was intimately tied to European modernity but that did not reproduce the autonomous "individual" of European political thought as a figure of its own desire.' ${ }^{26}$

Chakrabarty contrasts Lockean conceptions of the nation, in which an absolutist, paternally derived, power is replaced by a social contract between equal (male) individuals, with the early Bengali understanding of national unity as an expression of 'natural brotherhood'. (He is well aware that both versions exclude women.) The power of the Bengali patriarch did not, he argues, have to be jettisoned in the same symbolic way in order to enter modernity, partly because his authority was not seen as exercised through command but via the devotion of his sons. Familial bonds could then continue to play a part in the theorisation of the 'modern' nation. So when, for example, Lord Curzon announced, in 1905, the first partition of Bengal to divide the largely Muslim areas in the east from the largely Hindu areas in the west, the movement protesting this 'was rich in the symbolism of the country imagined as Mother and national unity as fraternal bond'. ${ }^{27}$ It was through the cultivation and widening of what was in some ways a very 'traditional' sentiment - the feeling of attachment to one's brother -that a national sentiment could emerge. This makes 
an illuminating contrast between different conceptions of modernity, but one point in Chakrabarty's account troubles me, as indeed it troubled him. As he notes, the invocation of a national unity framed in terms of brotherhood was inadequate when faced with the central issue of Indian nationalism, which was how to achieve unity across the HinduMuslim divide. Not surprisingly, 'Muslims did not buy this largely Hindu, upper-caste rhetoric of natural brotherhood. Nor did the lower castes, as the twentieth century progressed. ${ }^{28}$ He does not press this point, but one might well argue that the more abstract individual of Lockean modernity, however marked and constrained by exclusions of class, gender, and race, at least contained the potential to think beyond difference: to think of a unity in which it genuinely did not matter whether one was male or female, Hindu or Muslim, upper or lower caste. The figure of the abstract, autonomous individual continues to haunt notions of modernity even among those critical of its European focus.

\section{Legacies of colonialism}

Yet colonialism did little to promote this supposedly modern figure. To the contrary, one of its most cited legacies - at least in sub-Saharan Africa - is that it rigidified what was previously more fluid, especially as regards ethnic and communal identities. ${ }^{29}$ There were moments, particularly in the early years, when advocates of colonial expansion imagined the newly acquired territories as a tabula rasa on which they could inscribe whatever they chose. In particular, they expected to be able to introduce the private markets in land and 'free' wage labour that provide the economic underpinning of (what they deemed to be) modernity. But while the colonial states enjoyed a monopoly of military force and deployed this with frequent brutality, they were nonetheless dependent on a layer of local notables to mobilise labour, collect taxes, and settle disputes. Whatever their ideological preferences, whether they formally espoused direct or indirect rule, administrators everywhere had to respond to what Mamdani describes as the 'central and overriding dilemma: the native question. Briefly put, how can a tiny and foreign minority rule over an indigenous majority?'30 The answer, typically, was some version of indirect rule that selectively legitimised 'customary law' and 'traditional authority', picking out those elements that best served colonial imperatives and setting aside others. In British controlled West Africa, for example, the recalcitrance of local conditions, or all-too-fast uptake of new possibilities for private accumulation, soon encouraged a retreat to less ambitiously 
transformative plans. Faced with processes they could not easily control, colonial administrators came to comfort themselves with a romanticised scenario of independent small-holders, cultivating their lands under conditions of customary land tenure, and protected by a combination of chiefly and colonial power against the rise of freehold land and its counterpart, free wage labour. ${ }^{31}$ For those who still toyed with more ambitious dreams of capitalist accumulation, reports of the horrific killings in the Belgian Congo provided a sharp reminder of the disruptions associated with plantation agriculture. It need hardly be added that the romanticised vision of the colonial settlement was not the full story, but it conveys something of the ways in which colonialism sustained its power.

In most parts of Africa, the administration of the colonies then came to depend on the delegation of authority to selected 'tribal' leaders (the uncooperative ones were quickly removed), who were secured in their power through their role as now state-endorsed custodians of the land, and enabled through this to determine who had access and under what conditions. In return, they ensured a steady supply of forced labour, taxes, military recruits, and agricultural commodities. Their role as custodians was commonly referred to as reflecting a system of customary land tenure, as if it simply formalised practices from before the colonial conquest, but the authority granted to the newly recognised tribal authorities usually exceeded that of their predecessors. As Mamdani puts it, 'from African tradition, colonial powers salvaged a widespread and time-honored practice, one of a decentralized exercise of power, but freed that power of restraint, of peers or people. Thus they laid the basis for a decentralized despotism.' 32 The chiefs and local notables became more unrestrained in their authority, but also the fixing of boundaries between one community and another, and attachment of these to what was seen as tribal difference, made it harder for those not deemed to share the same ethnicity to move across the territories and gain access to new land. ${ }^{33}$ The winning of independence made less of a difference here than might have been hoped, for postcolonial rulers faced much the same constraints as regards their administrative capacity and the reach of their authority, and frequently incorporated these neocustomary authorities into their structures of governance. In Catherine Boone's analysis, 'chiefs and other neocustomary leaders often remained the gatekeepers, political brokers, and local strongmen they had been under colonial rule, 
mediating local citizens' access to land and local justice, and brokering access to opportunities (and exposure to risks) posed by government. ${ }^{34}$

One important consequence was the ethnicisation of land conflict. 'Across much of rural Africa, the definition of "who is a stranger" and the second-class status of strangers tended to harden over time, ${ }^{35}$ and this has proved particularly damaging at a time of increasing population pressure on the land. A further important consequence has been the strengthening of traditional authorities who then resist the rights of women to inherit the land or exercise power. Pre-colonial Africa was no matriarchal haven, but women had assumed important positions of leadership in some of the ancient empires of the continent, and as the example of the Queen Mothers of West Africa illustrates, had continued to exercise significant authority well into the colonial period. At a more decentralised level, 'most African societies had women's organisations which controlled or organised agricultural work, trade, the markets, and women's culture and its relevant ideology'; ${ }^{36}$ again, the market women of West Africa are a significant illustration. But while the colonial regimes employed, and in many instances magnified, the authority of male chiefs, they had no place in their conception of colonial rule for these forms of female power. Colonialism did little for women's rights, and nothing of significance as regards their rights to the land: again, this was not the world of private property and individual rights that some earlier exponents of imperialism's transformative power had anticipated.

Karuna Mantena has traced the ways these developments played out in imperial thinking within the metropolis - in her study, particularly within Britain - and identifies the Indian Mutiny of 1857 and Governor Eyre's brutal suppression of the Morant Bay rebellion in Jamaica in 1865 as key moments in the shift. ${ }^{37}$ What was once justified by reference to the 'civilising mission' and the capacity to bring 'backward' natives to a higher stage of civilization, came to be thought of more as a matter of maintaining order over peoples who were fundamentally different. 'In the transition from universalist civilizing justification to culturalist alibis for the maintenance of empire, social order and stability supplanted agendas of reform as the motivating ground of imperial rule.' ${ }^{38}$ Or as Mamdani similarly puts it, there was a 'midstream shift in perspective: from the zeal of a civilizing mission to a calculated preoccupation with holding power; from being the torchbearers of individual freedom to being custodians protecting the customary integrity of dominated tribes' ${ }^{39}$ 
With the 'turn to culture', those colonial subjects who had too willingly imbibed the lessons of Western civilization now became objects of disdain. The colonial administrators who most explicitly positioned themselves as defenders of what they conceived to be custom and tradition much preferred the dignified difference of traditional rulers to the now despised products of the missionary schools, with their ties and their umbrellas. Mantena cites Lord Lugard's disdain for the 'unstable', 'untrustworthy', Europeanized African as one example of this. ${ }^{40}$ Joyce Cary provides another in his description of a District Officer in the novel Mister Johnson.

His expression is mild and benign, but the truth is that he dislikes all Negro clerks and especially Johnson. He is a deeply sentimental man, a conservative nature. He likes all old things in their old places and he dreads all change, all innovation. To his mind, a messenger in a white gown, even if he speaks and writes English, is a gentleman; but a clerk in trousers, even if he can barely do either, is an upstart, dangerous to the established order of things. ${ }^{41}$

In colonial ideology, racial hierarchy often appeared in the guise of racial difference, with each regarded as worthy so long as he remained in his own place. But of course both the English-speaking messenger in the white gown and the upstart Christianised clerk in trousers were alike products of the colonial conquest; the former was no more representative of the old ways than the latter was representative of the new ones.

\section{Global Justice Theory}

How might any of this relate to questions of global justice? First, a caveat: it would not be entirely fair to say of global justice theory that it ignores historical causation. This might be a reasonable criticism as regards Peter Singer's drowning child scenario, which explicitly sets to one side whether the person under a moral obligation to rescue the child had any causal role in her ending up in the pond, and by extension, sets to one side whether those now called upon to address global poverty had any role in creating it. ${ }^{42}$ It would be less convincing as applied, say, to Pogge, who argues that 'existing peoples have arrived at their present levels of social, economic, and cultural development through a historical process 
that was pervaded by enslavement, colonialism, even genocide', and that 'the global economic order plays a major role in the persistence of severe poverty worldwide'. ${ }^{43}$ Here, the case for global redistribution is directly linked to an account of richer countries as historically responsible for the poverty of poorer ones. Environmental degradation, malnutrition, and starvation are traced to a global economy that continues to channel resources to people elsewhere.

One could not say, of this, that it treats what was produced by colonialism as if it were an original state. The perspective, however, remains very much that of the richer countries, and the references to colonialism work primarily to put pressure on the citizens and governments of these countries to recognise their responsibilities for global injustice and take remedial action. The key message is that justice cannot be contained within the narrow confines of the nation-state, and one effect of this is to render the specificities of each national context-including the specificities of each postcolonial context - as of lesser significance. Consider the two standard objections to global justice. These are, first, that people have compelling local attachments to their fellow citizens; secondly, that the problems of global poverty stem more from domestic failings, like corrupt elites, than from the workings of the global economy. Answering the first typically involves challenging the normative priority given to the nation state by citizens in the rich countries. Answering the second involves challenging the analytic priority given to the nation state within the postcolonial ones. On the first argument, we should not think the obligation to deliver justice stops at the border of the rich countries. On the second, we should not think the causes of injustice arise within the borders of the poor ones. Both responses push in the post-national, post-communal, post-ethnic direction that modernisation theory identifies as at the 'modern' rather than 'traditional' end of the spectrum.

The paradigm encourages us to bracket what goes on inside each country and treat it as both normatively and analytically of lesser importance. The history of colonialism then figures mainly as confirming the case for reparations, as demonstrating the responsibility of the richer countries and their obligations to the poorer ones. This is an important message: I am not arguing against reparations. But an exclusive focus on colonial wrongs is not always the most productive message for those living in the post-colonies. As the example of Zimbabwe under (the later) Mugabe suggests, the story of colonial depredations can 
become an alibi for governments unwilling to address the impact of their own policies, and refusing to acknowledge their own plundering of their citizens. Because it concentrates on global responsibility, global justice theory is inclined to gloss over more local causes of injustice. Because it focuses on person to person relations, it is inclined to ignore what happens at the level of the state. The normative framing encourages us to think primarily in terms of the global rich and global poor, abstract conglomerates of abstract individuals, identifiable mainly by location (global north or global south) and resources. This is not a particularly illuminating framework for addressing the political and economic structures that sustain inequality. Among other things, it means that those who continue to devote their energies to critical analysis of the aid relationship or the failings of postcolonial elites may be left feeling they are undermining the normative case for global justice, and providing too easy an escape route for those seeking to evade their responsibilities. Yet for those living in the post-colonies, analysis of these political and economic structures, local as well as global, might seem the most pressing task.

This is one potential failing of the global justice approach, but does not yet link it decisively to modernisation theory. The latter, after all, tends to focus quite closely on local structures and the obstacles these present to further development, and on that score is better understood as the target of much global justice theory rather than its ally. The two approaches nonetheless have a shared investment in a modernist mentality that regards the transcendence of difference as representing morality's highest stage. For modernisation theorists, including of the revised kind, development involves a transition from the closed communities of traditional society to the open-ended individualism of modern society: modernity is then understood as post national, post communal, post ethnic. Global justice theorists do not talk in the same way about development, but they operate with an understanding of normative maturity that involves a similar trajectory: we move beyond the local attachments that conceive of obligation as ending at the boundary of community or nation, and come to appreciate that justice is a global affair. There is no explicit theory of transition in this, and no endorsement of the language of tradition and modernity, but there is a related confidence about what counts as the higher stage. 'We' (in the richer countries) are not only represented as those with the obligations. We are also implicitly represented as those more capable of responding to the normative call to deliver global justice, because 
the centrality we already attach to the individual enables us to get beyond the limitations of either a statist or localist perspective.

In a critique of Pogge, Neera Chandhoke has argued that tying the obligation to remedy to the causal role one has played in creating the problem can limit rather than expand the scope of the obligation, and that those who can alleviate global poverty have an obligation to do so even if they are not institutionally connected in a causal chain. ${ }^{44} \mathrm{Her}$ argument is not just that the rich in the rich countries should not be able to get themselves off the hook by showing that they were not responsible for all the poverty in the world. She wants also to stress the obligations of the rich in the poorer countries, and argues that in failing to emphasise or include these, global justice theorists implicitly rate the inhabitants of poorer countries as of lesser moral status, as recipients of other people's actions rather than actors themselves. 'Are we,' she asks, 'who live and work in the developing world, fated to remain consumers of acts, whether these are acts of harm or of duty, performed by the West? Do those of us who live in India have any kind of duty to the poor in other countries? And if we do not, do we lack status as moral beings who count?' ${ }^{\prime 45}$ The worry, that is, is that in addressing itself so exclusively to the citizens of rich countries, global justice theory not only treats them as causally responsible and richer in resources, but perceives them as richer in agency too. My suggestion is that this is not just a perverse consequence of first world guilt. Insofar as the capacity for ethical action is being associated with the capacity to think beyond the local to the global, or beyond the national to the rights and obligations of the individual, it both blocks analysis of the structures sustaining inequality and conveys a normative hierarchy.

One element of this is that appealing 'beyond' difference to what then becomes an excessively abstract humanity threatens to deprive us of the collective resources on which mobilisations against injustice often depend. When people defend a local community against the power of global corporations (think of the Movement for the Survival of the Ogoni People against the power of Shell and the Nigerian National Petroleum Corporation), they rarely do so in a post-national, post-communal, post-ethnic framework. To the contrary, they often appeal to the values of their community, to principles of fairness or mutual concern they see as being swept aside by the juggernauts of modernity. There is typically some romanticisation of the past in this: the past, like the present, is always a 
mixture of good and bad, and nostalgia for tradition commonly obscures its less attractive aspects. But as a mobilising force, references to earlier but now threatened values are often more powerful than the abstract invocation of a common humanity. And there are good reasons for this, for one of the risks in invoking our common humanity is that this can encourage us to think of our humanness as distinct from the specificities that characterise us: to think of it as a kind of transcendence, an ability to set aside the particularities, those supposedly less essential aspects of ourselves. We do, indeed, need to make connections with those we perceive as different from ourselves - this is the important truth in appeals to our common humanity - but this does not (and cannot) require transcendence of all difference. When connecting across difference is presented as a matter of refusing to attach significance to that difference, this discourages analysis of the structures that continue to turn that difference into inequality. It also encourages the view that difference per se is a problem, something we need mentally to erase in order to embrace that commonality. Against this view, it is important to stress that we are not human instead of but as ...women, men, black, white, gay, lesbian, heterosexual, Fante, Hausa, Igbo. These are not exclusive alternatives, though they are too often presented as such within the framework of a methodological or normative individualism.

There is a particularly compelling articulation of this point in a speech Hannah Arendt gave on the occasion of receiving the Lessing Prize in 1959. This was her first return to Germany since being obliged to leave the country in 1933 , and she used the occasion to reflect critically on the notion of the human and invocations of our common humanity, and how little these supposedly inclusive ideals had been able to achieve in those 'dark times'. When Jewishness carried such life and death significance, she saw it as evasion simply to insist on a shared humanity.

'(I)n the case of a friendship between a German and a Jew under the conditions of the Third Reich it would scarcely have been a sign of humanness for the friends to have said: Are we not both human beings? It would have been mere evasion of reality and of the world common to both at that time; they would not have been resisting the world as it was. A law that prohibited the intercourse of Jews and Germans could be evaded but could not be defied by people who denied the reality of the distinction. In keeping with a humanness that had not lost the solid ground of 
reality, a humanness in the midst of the reality of persecution, they would have had to say to each other: A German and a Jew, and friends. ${ }^{46}$

The parallel context, for much of the previously colonised world, is an institutionalisation of ethnic and community identity that cannot be defied by people who simply deny the reality of the distinctions. In Africa today, it is of course possible to refuse the identifications, to espouse a cosmopolitan humanism that attaches no significance to them. But this would be a matter of individual stance or attitude, and of itself hardly begins the work of dismantling the structures that can make those ethnic and community identifications so lethal. The effect, moreover, is very often to institute a new kind of hierarchy, through which the progressive-minded and usually urban dweller marks his distance from the benighted rural population. ${ }^{47}$ The modern, again, becomes associated with the capacity to think of oneself as abstracted from social context, to question received beliefs, inherited norms, or ascribed identities; and the capacity to do this becomes elevated into the mark of normative maturity.

To clarify, I am not arguing against attaching normative weight to individuals; I am not seeking to defend tradition against modernity; I am not even arguing for a more communitarian understanding of the individual, though I will happily settle for a more relational one. As I hope has become clear, I see contrasts between traditional and modern, revolving as they so often do around further contrasts between particularity and universality, or embeddedness in one's social relations and the capacity for abstracting oneself from these, as obscuring the interweaving of the so-called traditional and so-called modern in pretty much every known society. More specifically, my comments on the legacies of colonialism are intended to convey scepticism about what gets named as 'tradition' in societies that were subjected to the upheavals of colonial rule. I am not then endorsing the kind of cultural revivalism that uncritically reclaims those past traditions as alternatives for the future. ${ }^{48}$ My claim, more simply, is that a normative theory that revolves around the abstraction of the individual - and the capacity of that individual to abstract herself from her surroundings - participates, however inadvertently, in a binary of traditional and modern.

Global justice theory enacts its modernity by refusing the significance of substantive characteristics beyond location (X lives in the global north not south) or resources ( $\mathrm{X}$ is rich 
rather than poor). This simultaneously obscures the structures that sustain inequality structures that are local as well as global - and endorses an ethical framework that calls on us to set aside local and national loyalties. This is not particularly meant for those living in the post-colonies, on the (often reasonable) grounds that they are the ones who were wronged, not the ones with the duties of justice. My point is that it could not be addressed to them, for an exhortation to set aside the private, local, and communal, and disregard national commitments and concerns is too patently at odds with the challenges people face in the worlds created through the colonial encounters. Global justice claims to address us all in our shared humanity, but in reality speaks only to some, and in doing so becomes vulnerable to the charge of dividing the world into an 'us' and 'them'. The 'us' are figured as having arrived at the stage where they can at last set aside local loyalties while the 'them' are not really figured at all.

One might, of course, argue that it is precisely in contexts where there is an excess of attachment to the ethnic or local that global justice theory comes into its own: that its great strength lies in the resources it offers for challenging ethnic, gender and national exclusions. There is something in this, but not enough. As critics of race-blind and gender-blind approaches to inequality have repeatedly argued (including, in this volume, Charles Mills), while the high-minded refusal to regard differences of gender, ethnicity or nationality can, in some contexts, alleviate discrimination, it can also close down analysis of the structures that reproduce the inequalities and discrimination, and block initiatives for change. The challenge is to find ways of mobilising the ethical imperative that underpins global justice theory without obscuring the history in which it is embedded: to find ways of pursuing justice that do not rebound on themselves by enacting a normative hierarchy. 
Footnotes

${ }^{1}$ I am grateful to the participants at the conference on Empire, Race and Global Justice for their comments on the first version of this paper, and particularly to Duncan Bell for thoughtful comments and suggestions. I am also grateful to Katrin Flikschuh, Cathy Boone, and Peter Niesen for comments on an earlier draft.

${ }^{2}$ See Katrin Flikschuh (2014), 'The Idea of Philosophical Fieldwork: Global Justice, Moral Ignorance, and Intellectual Attitudes' Journal of Political Philosophy, 22: 1-26; Neera Chandhoke 'How much is enough, Mr Thomas? How much will ever be enough?' In Alison M. Jaggar (ed.), Thomas Pogge and His Critics. Cambridge, Polity, 2010).

${ }^{3}$ As reflected in Leif Wenar's title, (2003) 'What Do We Owe to Distant Others?' Politics, Philosophy and Economics, 2/3: 283-304.

${ }^{4}$ As Stuart Hall put it in 'The Local and the Global' in Anthony King (ed) Culture, Globalisation, and the World System: Contemporary Conditions for the Representation of Identity (Albany, SUNY Press, 1989)

${ }^{5}$ This is the question, for example, that underpins Laura Valentini's exploration of the challenges of global justice in Justice in a Globalized World: A Normative Account (Oxford University Press, 2011).

${ }^{6}$ Margaret Kohn (2013) 'Postcolonialism and global justice' Journal of Global Ethics 9/2: 187200

7 Thomas Pogge (2002) World Poverty and Human Rights: Cosmopolitan Responsibilities and Reforms Cambridge: Polity Press: 169. The second element is 'universality: the status of ultimate unit of concern attaches to every living human being equally-not merely to some subset, such as men, aristocrats, Aryans, whites, or Muslims. Third, generality: this special status has global force. Persons are ultimate units of concern - not only for their compatriots, fellow religionists, or suchlike.'

${ }^{8}$ Realism thinks it both appropriate and inevitable that states will pursue their own national interests; nationalism that people have special obligations to their fellow nationals; and 'the society of states' regards international justice as best conceived in terms of what states might owe to other states, rather than what individuals might owe to the poor. Simon Caney Justice Beyond Borders: A Global Political Theory (Oxford University Press, 2005). 
${ }^{9}$ Daniel Butt Rectifying International Injustice: Principles of Compensation and Restitution Between Nations (Oxford: Oxford University Press, 2008). Butt is then closer to Caney's 'society of states' category, but it would be odd not to include him in the general camp of global justice theory.

${ }^{10} \mathrm{He}$ argues, for example, that the principles that ought to govern international interaction are 'strikingly similar to the principles which libertarian theorists, such as Robert Nozick, believe govern interaction between individuals at a domestic level'. Rectifying International Injustice: 8-9.

${ }^{11}$ This is part of what Catherine Lu then challenges in her structural account of injustice. 'Colonialism as Structural Injustice: Historical Responsibility and Contemrpoary Redress' The Journal of Political Philosophy 19/3, 2011: 261-281.

12 Paper in this collection, See also Samuel Moyn 'The Political Origins of Global Justice' ${ }^{13}$ Mahmood Mamdani Citizen and Subject: Contemporary Africa and the Legacy of Late Colonialism (Princeton University Press, 1996): 48

${ }^{14}$ Thomas Pogge 'Concluding Reflections' in G. Brock (ed) Cosmopolitanism versus nonCosmopolitanism (Oxford, Oxford University Press, 2013): 298

${ }^{15}$ Walt W. Rostow (1959) 'The stages of economic growth' The Economic History Review 12/1: 1-16; Politics and the Stages of Growth (Cambridge: Cambridge University Press, 1971); The Stages of Economic Growth: A non-communist manifesto (Cambridge: Cambridge University Press, 1990)

${ }^{16}$ For example, Gabriel A. Almond and Sidney Verba The Civic Culture: Political Attitudes and Democracy in Five Nations (Little, Brown, 1963); David E. Apter The Politics of Modernization.(Chicago: University of Chicago Press, 1967). For an overview of early modernisation theory see Henry Bernstein, (1971) 'Modernization theory and the sociological study of development' .Journal of Development Studies, 7/2: 141-160 17 Dipesh Chakrabarty Provincializing Europe: Postcolonial Thought and Historical Difference (Princeton University Press, 2000)

${ }^{18}$ Immanuel Wallerstein (1976) 'Modernization: Requiescat in Pace' in L. Coser and O Larsen (eds) The Uses of Controversy in Sociology (New York: Free Press) 19 Including Robert M Marsh (2014) 'Modernization Theory, Then and Now' Comparative Sociology 13: 261-283. 
${ }^{20}$ Ronald Inglehart and Christian Welzel (2005) Modernization, Cultural Change, and Democracy: The Human Development Sequence (Cambridge: Cambridge University Press): 46

${ }^{21}$ Inglehart and Welzel Modernization, Cultural Change, and Democracy: 46

${ }^{22}$ Andre Gunder Frank The development of underdevelopment. (Boston, MA: New England Free Press, 1966)

${ }^{23}$ Thomas Piketty Capital in the Twenty-First Century (Harvard University Press, 2013).

${ }^{24}$ Thomas McCarthy Race, Empire and the Idea of Human Development (Cambridge, Cambridge University Press, 2009): 156.

${ }^{25}$ McCarthy works broadly within the tradition of critical theory. As Amy Allen argues in The End of Progress: Decolonizing the Normative Foundations of Critical Theory (Columbia Ungoriest Press, 2016), critical theory has faced particular difficulties in rescuing what is positive in ideas of progress, development and modernity from what is problematic in progressivist theories of history.

${ }^{26}$ Chakrabarty, Provincializing Europe: 218.

27 Chakrabarty Provincializing Europe: 234

${ }^{28}$ Chakrabarty Provincializing Europe :234

${ }^{29}$ Terence Ranger 'The Invention of Tradition in Colonial Africa', pp211-262 in Eric Hobsbawn and Terence Ranger (eds) The Invention of Tradition Cambridge University Press, 1983; Mahmood Mamdani Citizen and Subject: Contemporary Africa and the Legacy of Late Colonialism Princeton University Press, 1996.

30 Mamdani Citizen and Subject: 16

${ }^{31} \mathrm{I}$ explore this story in The Enigma of Colonialism (London, James Currey, 1989). For a parallel account of Kenya see John Lonsdale and Bruce Berman (1979) 'Coping with the contradictions: the development of the colonial state in Kenya, 1895-1914' Journal of African History 20: 487-505.

32 Mamdani Citizen and Subject: 48

${ }^{33}$ For an account of the ethnicisation of land entitlements, see Catherine Boone Property and Political Order in Africa: Land Rights and the Structure of Politics (Cambridge, Cambridge University Press, 2014)

${ }^{34}$ Boone Property and Political Order in Africa: 26 
${ }^{35}$ Boone Property and Political Order in Africa: 33

${ }^{36}$ Ifi Amadiume 'Gender, Political Systems and Social Movements: a West African

Experience' pp35-68 in Mahmood Mamdani and Ernest Wamba-dia-Wamba (eds) African

Studies in Social Movement and Democracy (Senegal, CODESRIA, 1995): 36

${ }^{37}$ Karuna Mantena Alibis of Empire: Henry Maine and the Ends of Liberal Imperialism (Princeton University Press 2010).

${ }^{38}$ Mantena Alibis of Empire: 160

39 Mamdani Citizen and Subject: 286

${ }^{40}$ Mantena Alibis of Empire: 174 Lugard was the architect - or at least exponent - of principles of indirect rule, as derived from his experience in Nigeria. The Dual Mandate in British Tropical Africa, 1922

${ }^{41}$ Joyce Cary (1939) Mister Johnson (London, Penguin, 1962 edition):25

42 Peter Singer (1971) 'Famine, Affluence, and Morality' Philosophy and Public Affairs 1/3: $229-243$

43 Thomas Pogge (2004) "' Assisting" the Global Poor': 534, 537

${ }^{44}$ This suggests a position closer to that of Singer, though her critique of the causal model also resonates with some of the arguments developed by Iris Marion Young in Responsibility for Justice OUP 2011.

${ }^{45}$ Chandhoke 'How much is enough, Mr Thomas? : 80

${ }^{46}$ Hannah Arendt 'On Humanity in Dark Times: Thoughts About Lessing' (1959) pp3-32 in Arendt, Men in Dark Times (San Diego and New York: Harcourt Brace, 1983):23

47 One of the arguments Mamdani makes in Citizen and Subject is that strategies of topdown modernization, aimed at detribalising power, may just replace a decentralised despotism by a centralised one, in ways that exacerbate the urban/ rural divide.

${ }^{48}$ I am sceptical, for example, about some of the ways in which ubuntu is invoked in some current discourses about the individual and community in Africa: for example, in Drucilla Cornell's Law and Revolution in South Africa: uBuntu, Dignity, and the Struggle for Constitutional Transformation (New York: Fordham University Press, 2014). 